\title{
IMPACT OF THE COVID-19 PANDEMIC ON THE TREATMENT OF PATIENTS WITH IMMUNOMEDIATED RHEUMATIC DISEASES USING ANTIMALARIALS IN THE CITY OF MANAUS/AMAZONAS
}

Clara Pinheiro Martins ${ }^{1, \star}$, Cecília Tizatto Barroso1, Gabriella Bacellar Marques ${ }^{1}$, Samuel Elias Basualto Dias ${ }^{1}$, Vitória Miki Pang

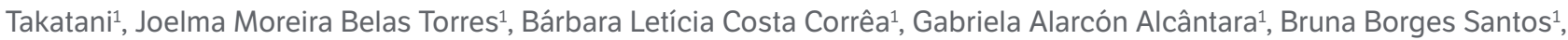
Gabriel Antônio de Lima Cerqueira ${ }^{1}$, Bruna Guimarães Dutra ${ }^{1}$, Laura Ribeiro Aref Kzam¹, Andrezza Mendes Franco ${ }^{1}$, Helena Lúcia Alves Pereira ${ }^{1}$, Sandra Lúcia Euzébio Ribeiro ${ }^{1}$

1.Universidade Federal do Amazonas, Manaus (AM), Brazil.

*Corresponding author: mp.clara9@gmail.com

\section{BACKGROUND}

Antimalarials (chloroquine and hydroxychloroquine) are a class of drugs used in medical practice, especially in patients with immunemediated rheumatic diseases (IMRD), such as those diagnosed with systemic lupus erythematosus (SLE) followed by rheumatoid arthritis (RA) and Sjögren's syndrome (SS). During the severe acute respiratory syndrome coronavirus 2 (SARS-Cov2) pandemic period, some studies have demonstrated a possible action of antimalarials (AM) against the coronavirus disease 2019 (COVID-19) virus. Thus, there was a great increase in the demand for the medication, creating a shortage in stock for those who already use AM. The objective of the study is to demonstrate how the pandemic impacted the treatment of these patients with IMRD using AM.

\section{MATERIALS AND METHODS}

Observational and cross-sectional study, based on data analysis of patients with IMRD from the Mário Pinotti II Project, organized by the Brazilian Society of Rheumatology (BSR), in the city of Manaus/Amazonas. The information analyzed was about antimalarials, time and frequency of use, form of acquisition and also reason and time of interruption of AM. The study was approved by the Ethics Committee.

\section{RESULTS}

Among the 311 patients analyzed, hydroxychloroquine $400 \mathrm{mg}$ (92.6\%) was the AM most used by patients, followed by chloroquine diphosphate $150 \mathrm{mg}, 250 \mathrm{mg}, 200 \mathrm{mg}$ and chloroquine - base salt (0.3\%). The average time of use was 6.7 years, the frequency varied from three to seven days a week ( 5.8 and $76.2 \%$, respectively). In relation to the acquisition of AM, 64.3\% purchase with their own resources and for $35.7 \%$ the medication was made available by CEMA/SUS (central of medicine). In the period from March to August/2020,30.2\% of patients discontinued the use of AM, notably due to the unavailability of AM in the public and private network (85.1\%). Such interruption was temporary, as the Project Mário Pinotti Il team and the BSR mobilized efforts to ensure that patients received $A M$, through donation delivered to the Ambulatório Araujo Lima, avoiding further damage to treatment.

\section{CONCLUSION}

Therefore, the dissemination in the media of the use of AM for the treatment of SARS-Cov2 led to the indiscriminate use of AM by the population, generating a shortage of the medication, which could have a direct impact on patients with IMRD using AM, since a significant portion of the patients had their treatment interrupted. The donation guaranteed the patients treatments maintenance and the benefits of the continuous use of $\mathrm{AM}$ in the clinical control of the disease.

\section{REFERENCES}

1. Georgiev T. Coronavirus disease 2019 (COVID-19) and anti-rheumatic drugs. Rheumatol Int. 2020;40(5):825-26. https://doi. org/10.1007/s00296-020-04570-z

2. Rainsford KD, Parke AL, Clifford-Rashotte M, Kean WF. Therapy and pharmacological properties of hydroxychloroquine and chloroquine in treatment of systemic lupus erythematosus, rheumatoid arthritis and relate diseases. Inflammopharmacology. 2015;23(5):231-69. https://doi.org/10.1007/s10787-015-0239-y

3. Rivera LMS, Ávila DF, Molano WB, Arroyave DJ, Ramírez AJB, Maldonado AD, et al. Recomendaciones sobre el manejo de pacientes adultos con enfermedades reumáticas en el contexto de la infección por SARS-CoV-2/COVID-19. Asociación Colombiana de Reumatología Clínica. 2020;16(6):437-46. 